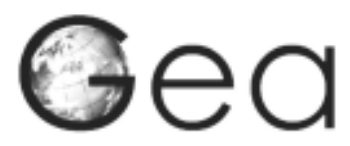

JURNAL PENDIDIKAN GEOGRAFI

\title{
PENERAPAN PENDEKATAN KETERAMPILAN PROSES UNTUK MENINGKATKAN PRESTASI BELAJAR SISWA PADA MATA PELAJARAN GEOGRAFI
}

\author{
(Studi Eksperimen Terhadap Siswa Kelas X Pada Materi Atmosfer \\ Di SMAN 11 Kota Bandung) \\ Indah Purwanti'); Dadang Sungkawa ${ }^{2)}$; Ahmad Yani ${ }^{3)}$ \\ 1) 2) 3) Jurusan Pendidikan Geografi, FPIPS UPI \\ email: ahyani_07@yahoo.co.id
}

\begin{abstract}
ABSTRAK
Banyak metode pembelajaran yang sudah dikembangkan berpusat pada siswa dengan tujuan untuk meningkatkan prestasi belajar siswa. Salah satunya adalah pendekatan Keterampilan Proses yang diterapkan pada materi Atmosfer dan Dampaknya Bagi Kehidupan Di Bumi. Penelitian ini dilakukan untuk mengetahui seberapa besar metode pendekatan Keterampilan Proses memberikan peningkatan yang signifikan terhadap prestasi belajar siswa pada mata pelajaran geografi. Metode yang digunakan pada penelitian ini adalah metode eksperimen. Subjek eksperimen adalah siswa-siswa kelas X SMAN 11 Kota Bandung Tahun Ajaran 2008/2009. Kelas X-3 sebagai kelompok eksperimen dan kelas X-5 sebagai kelompok kontrol. Pada kelompok eksperimen menggunakan metode pendekatan Keterampilan Proses sedangkan pada kelompok kontrol menggunakan metode ceramah bervariasi yang biasa digunakan oleh guru di sekolah. Teknik pengumpulan data menggunakan tes objektif berupa pilihan ganda, sedangkan analisis data menggunalkan cara statistik, yaitu uji normalitas data menggunakan uji chi kuadrat, uji homogenitas data menggunakan uji $\mathrm{F}$, dan uji hipotesis menggunakan uji t. Hasil penelitian menunjukkan bahwa terdapat peningkatan prestasi belajar siswa yang dilihat dari hasil pre test dan post test pada kelompok eksperimen yang menggunakan metode pendekatan keterampilan proses. Peningkatan hasil belajar siswa tersebut berdasarkan hasil uji hipotesis dimana $\mathrm{H}_{1}$ diterima dan $\mathrm{Ho}$ ditolak ( $t_{\text {hitung }}=7,91$ dan $\mathrm{t}_{\text {tabel }}=1,997$ ). Terdapat peningkatan hasil belajar siswa antara hasil pre test dan post test pada kelompok kontrol yang menggunakan metode ceramah bervariasi dengan $\mathrm{H}_{1}$ diterima dan Ho ditolak ( $\mathrm{t}_{\text {hitung }}=7,51$ dan $\mathrm{t}_{\text {tabel }}=1,997$ ). Selain itu terdapat perbedaan hasil belajar siswa antara kelompok eksperimen dan kelompok kontrol, namun dengan $\mathrm{H}_{1}$ ditolak dan Ho diterima ( $\mathrm{t}_{\text {hitung }}=0,42$ dan $\left.\mathrm{t}_{\text {tabel }}=1,997\right)$. Hal tersebut dikarenakan perbedaan hasil belajar siswa antara kelompok eksperimen dan kelompok kontrol tidak signifikan. Hasil tersebut dilihat dari rata-rata gain kelompok eksperimen sebesar 4,47 dan kelompok kontrol 4,24 yang hanya memiliki selisih 0,23.

Kata kunci: Pendekatan keterampilan proses, prestasi belajar.
\end{abstract}




\section{PENDAHULUAN}

\section{Latar Belakang}

Penyelenggaraan pendidikan di sekolah, tentu tidak terlepas dari peran serta guru dalam melaksanakan proses pembelajaran siswa, yang diwujudkan dalam bentuk interaksi belajar mengajar, baik antara pendidik dengan pendidik lainnya, pendidik dengan peserta didik, maupun peserta didik dengan peserta didik dan lingkungannya.

Proses pembelajaran di sekolah tidak lepas dari suatu masalah yang dihadapi. Siswa mendapatkan bahan untuk pembelajaran hanya dari materi yang disampaikan oleh guru dengan menggunakan metode ceramah dan dari buku teks yang dimiliki oleh para siswa selama mengikuti proses pembelajaran.

Guru merupakan faktor yang menentukan upaya peningkatan mutu pendidikan. Guru harus mampu melakukan pembelajaran yang dapat memotivasi siswa untuk belajar. Pengajaran merupakan proses yang ditata dan diatur sedemikian rupa menurut langkah-langkah tertentu agar pelaksanaannya dapat mencapai hasil yang ditetapkan. Keberhasilan belajar siswa salah satunya dapat dilihat dari prestasi belajar yang dicapai seperti yang dikemukakan oleh Ali (1992:9) bahwa "Prestasi belajar yang dicapai siswa dijadikan tolak ukur kemampuan yang dimilikinya". Untuk mencapai keberhasilan proses pembelajaran, maka guru sebagai tenaga pendidik dituntut kemampuan dan tanggungjawabnya dalam memilih dan menentukan pendekatan-pendekatan pembelajaran yang mampu membangkitkan serta memelihara minat, motivasi, dan hasil belajar siswa melalui bidang studi yang diajarkannya.

Seorang guru juga dituntut untuk dapat menampilkan keahliannya menyampaikan materi pembelajaran secara efektif dan efisien. Dalam menyusun suatu strategi belajar mengajar, guru tidak lepas dari pemilihan metode dan pendekatan pembelajaran. Salah satu pendekatan pembelajaran yang memungkinkan terciptanya situasi yang memunculkan partisipasi aktif siswa, salah satunya adalah pendekatan keterampilan proses.

Berdasarkan hal tersebut diatas, peneliti akan mencoba melakukan perlakuan dengan menggunakan pendekatan keterampilan proses yang bertujuan untuk meningkatkan prestasi belajar siswa. Pendekatan keterampilan proses diharapkan dapat mengembangkan kemampuan intelektual siswa dan dapat meningkatkan peranan dan kompetensi guru sebagai fasilitator bagi siswa dalam meningkatkan prestasi belajarnya.

Pendekatan keterampilan proses merupakan suatu pendekatan dalam proses pembelajaran siswa yang mengarahkan siswa belajar dari lingkungannya terutama dari suatu peristiwa alam. Melalui lingkungan dan suatu peristiwa alam, siswa diharapkan dapat memiliki pengetahuan dan dapat mengungkapkan suatu permasalahan yang timbul serta dapat menemukan suatu konsep atau fakta baru. Pendekatan keterampilan proses ini memandang siswa sebagai manusia secara seutuhnya, pandangan tersebut dijabarkan dalam kegiatan belajar mengajar dengan memperhatikan pengembangan pengetahuan, sikap, nilai serta keterampilan. Ketiga unsur tersebut menyatu dalam satu individu yang terampil dalam bentuk kreativitas.

Peneliti berharap dengan melakukan pendekatan keterampilan proses ini, siswa dapat meningkatkan prestasi belajarnya. Pendekatan ini juga diharapkan dapat meningkatkan kompetensi guru dalam kegiatan belajar mengajar. Guru yang berkompeten akan lebih mampu menciptakan lingkungan belajar yang efektif dan mampu mengelola kelasnya sehingga prestasi belajar siswa berada pada tingkat yang optimal.

Penelitian ini akan dilakukan di SMAN 11 Kota Bandung, yang akan membandingkan prestasi belajar siswa dengan menggunakan metode ceramah bervariasi yang biasa digunakan oleh 
guru di sekolah sebagai kelas kontrol dan pendekatan keterampilan proses sebagai kelas eksperimen. Maka berdasarkan latar belakang masalah di atas peneliti akan melakukan penelitian eksperimen dengan judul "Penerapan Pendekatan Keterampilan Proses Untuk Meningkatkan Prestasi Belajar Siswa Pada Mata Pelajaran Geografi”.

\section{Rumusan Masalah}

Bagaimanakah prestasi belajar siswa sebelum menggunakan pendekatan keterampilan proses pada kelas eksperimen dan sebelum menggunakan metode ceramah bervariasi pada kelas kontrol? Rumusan masalah tersebut dijabarkan pada pertanyaan penelitian sebagai berikut: 1) Bagaimanakah prestasi belajar siswa setelah menggunakan pendekatan keterampilan proses pada kelas eksperimen dan setelah menggunakan metode ceramah bervariasi pada kelas kontrol? 2) Apakah ada pengaruh pendekatan keterampilan proses terhadap prestasi belajar siswa pada mata pelajaran Geografi Siswa Kelas X Di SMAN 11 Kota Bandung?

\section{Tujuan dan Manfaat Penelitian}

Tujuan penelitian ini adalah : 1) Untuk meningkatkan prestasi belajar siswa dengan menggunakan Pendekatan Keterampilan Proses pada mata pelajaran geografi; 2) Untuk mengetahui seberapa besar pengaruh penggunaan Pendekatan Keterampilan Proses pada mata pelajaran geografi.

Manfaat Penelitiannya adalah : 1) Bagi guru : Dapat menggunakan Pendekatan Keterampilan Proses dalam pembelajaran Geografi dan untuk mengetahui pengaruh Pendekatan keterampilan Proses sehingga tidak terpaku pada satu model pembelajaran saja; 2) Bagi siswa : Dapat meningkatkan motivasi, prestasi belajar, dan pengetahuan siswa melalui pengalaman belajar dari situasi kehidupan nyata; dan 3) Bagi peneliti : Dapat menambah pengetahuan dan wawasan tentang proses belajar mengajar di kelas maupun di lapangan.

\section{METODE PENELITIAN}

Penelitian ini bertujuan untuk mengetahui pengaruh pendekatan keterampilan proses terhadap prestasi belajar siswa, maka metode penelitian yang digunakan adalah metode eksperimen. Sedangkan disain penelitian yang digunakan adalah Randomized Control Group Pretest-Posttest Design. Pada desain penelitian ini kelompok eksperimen dan kelompok kontrol diberikan tes awal dan tes akhir. Selamjutnya dicari perbedaan (gain) antara kelompok eksperimen dan kelompok kontrol. Kemudian gain yang didapat dari dua kelompok komtrol diuji signifikansi perbedaan dua mean.

Berdasarkan keterangan yang dipaparkan, maka yang menjadi subjek penelitian ini adalah siswa kelas X-3 dan siswa kelas X-5 di SMAN 11 Kota Bandung, masing-masing kelas memiliki jumlah siswa sebanyak 35 dan secara keseluruhan maka jumlah siswa pada penelitian sebanyak 70 siswa. Adapun sebagai variabel bebas dalam penelitian ini adalah pendekatan keterampilan proses yang digunakan pada kelompok eksperimen. Sedangkan Variabel terikat adalah hasil yang terjadi karena variabel bebas. Pada penelitian ini adalah prestasi belajar. Setelah data yang diperlukan terkumpul maka dilakukan pengolahan data tersebut. Data yang terkumpul adalah data mentah yang merupakan skor total yang diperoleh setiap siswa dari hasil tes awal dan tes akhir untuk kelas eksperimen dan kelas kontrol. Langkah-langkah yang ditempuh dalam mengolah data tes adalah sebagai berikut: penskoran, uji normalitas dengan Chi Kuadrat, uji homogenitas dengan Uji F, dan uji hipotesis dengan Uji-t. 


\section{HASIL DAN PEMBAHASAN}

\section{Lokasi Penelitian}

Lokasi pada penelitian ini bertempat di SMAN 11 Kota Bandung. SMAN 11 Kota Bandung bertempat di Jl. Kembar Baru No. 23, Moh. Toha, Kecamatan Regol Kota Bandung. Secara de facto SMAN 11 Kota Bandung sudah berdiri sejak tahun 1967/1968 dan dikukuhkan dengan keputusan Depdikbud tanggal 8 April 1968 dengan nama SMA XI Bandung. Pada awalnya SMAN 11 Bandung merupakan kelas jauh yang semula menginduk kepada SMAN IV Bandung.

Pada tahun ajaran 2008/2009 SMAN 11 Kota Bandung memiliki 3 program belajar dan memiliki 1156 siswa, dimana jumlah siswa laki-laki sebanyak 476 dan siswa perempuan sebanyak 680. Pembagian Program belajar di SMAN 11 Kota Bandung belajar diantaranya yaitu:

1. Program Umum, untuk siswa kelas satu sebanyak 9 kelas dengan jumlah siswa laki-laki 143 dan siswa perempuan 207.

2. Program IPA, sebanyak 6 kelas untuk kelas XI dengan jumlah siswa laki-laki sebanyak 94 dan siswa perempuan sebanyak 141, sedangkan program IPA untuk kelas XII sebanyak 5 kelas dengan jumlah siswa laki-laki 89 orang dan siswa perempuan 150 orang.

$$
\text { 3. } 43
$$

Program IPS, sebanyak 4 kelas untuk kelas XI dengan jumlah siswa laki-laki 152 orang dan siswa perempuan 230 orang, sedangkan pogram IPS untuk kelas XII terbagi menjadi 5 kelas dengan jumlah siswa laki-laki sebanyak 181 dan siswa perempuan sebanyak 243.

SMAN 11 Kota Bandung memiliki 58 orang guru tetap dan 12 orang guru tidak tetap, yang memiliki tingkat pendidikan Diploma, S1, dan S2. Jumlah guru laki-laki di SMAN 11 Kota Bandung yaitu sebanyak 30 orang sedangkan guru perempuan sebanyak 38 orang.

\section{Proses Selama Penerapan Pendekatan Keterampilan Proses}

Proses pembelajaran dengan menggunakan pendekatan keterampilan proses ini dilakukan pada kelas eksperimen yaitu kelas X-3 pada materi Atmosfer dan Dampaknya bagi Kehidupan di Muka Bumi karena kelas tersebut belum mendapatkan materi tentang Atmosfer. Sebelum mendapatkan proses pembelajaran dan proses pengamatan, siswa terlebih dahulu diberi tes awal (pre test) untuk mengetahui kemampuan awal siswa.

Setelah diberi tes awal (pre test) guru memberikan sebagian penjelasan materi yang berkaitan dengan proses pengamatan. Guru memberikan rencana dan arahan untuk proses pengamatan keadaan cuaca dan iklim di wilayah Bandung Kota kepada siswa. Guru membagi siswa kedalam 7 kelompok pengamatan, masing-masing kelompok beranggotakan 5-6 orang secara heterogen. Guru membuat lembar pengamatan untuk jangka waktu 10 hari yang dimulai pada pukul 07.00 pagi sampai pukul 18.00 .

Proses pengamatan tersebut dilakukan mulai dari tanggal 9 Mei sampai tanggal 18 Mei 2009. Alat yang digunakan adalah termometer suhu untuk mengukur keadaan suhu selama 6 jam serta menggunakan indera untuk mengamati keadaan angin, awan, sinar matahari, dan hujan. Lokasi pengamatan yaitu di sekolah dan di rumah.

Setelah proses pengamatan tersebut berakhir, pada pertemuan berikutnya guru bersamasama dengan siswa membahas proses pengamatan yang telah dilakukan. Guru menyuruh siswa 
untuk menyampaikan hasil analisis proses pengamatan selama 10 hari, setelah siswa menyampaikan hasil analisisnya kemudian mereka mengajukan beberapa pertanyaan berdasarkan pengamatan yang dilakukan. Guru menyuruh siswa untuk mendiskusikan pertanyaan tersebut bersama kelompoknya masing-masing dan selanjutnya mengemukakan jawaban pertanyaan tersebut kepada kelompok lainnya. Guru dan siswa bersama-sama membuat kesimpulan berdasarkan pertanyaan yang telah diajukan.

Pada pertemuan selanjutnya guru mengulas materi yang telah disampaikan sebelumnya. Guru menyediakan data curah hujan bulanan daerah Bandung Kota dan dibagikan kepada setiap kelompok. Pembagian data tersebut bertujuan untuk mencocokkan hasil pengamatan di lapangan dengan proses perhitungan dengan menggunakan data sekunder. Dalam proses pengamatan tersebut, hasil analisis dari setiap kelompok bahwa Bandung Kota keadaan cuacanya dingin dan sering turun hujan. Setiap kelompok menghitung tipe iklim berdasarkan rumus Schimdt-Ferguson. Setelah mereka melakukan penghitungan ternyata hasilnya sama dengan hasil analisis pengamatan, bahwa keadaan iklim Bandung Kota saat itu dingin.

Setelah siswa selesai melakukan diskusi kelompoknya, guru dan siswa bersama-sama membahas tentang materi secara keseluruhan dan membuat kesimpulan dari seluruh proses pembelajaran. Guru memberikan tes akhir (post test) kepada siswa untuk mengetahui peningkatan prestasi belajar setelah dilakukan proses pembelajaran dengan menggunakan pendekatan keterampilan proses.

\section{Tanggapan Siswa Terhadap Pembelajaran Keterampilan Proses}

Data hasil tanggapan siswa terhadap kegiatan pembelajaran keterampilan proses diperoleh dari angket pernyataan yang diberikan kepada siswa. Untuk mengetahui hasil data tanggapan siswa dapat dilihat pada tabel berikut ini :

Tabel 4.0

Tabel Distribusi Frekuensi Tanggapan Siswa Terhadap Pembelajaran Keterampilan Proses Pada Mata Pelajaran Geografi

\begin{tabular}{|c|c|c|c|}
\hline No & Interval Kelas & Frekuensi & Frekuensi (\%) \\
\hline 1 & 10-19 & 5 & $14,28 \%$ \\
\hline 2 & $20-29$ & 7 & $20 \%$ \\
\hline 3 & $30-39$ & 15 & 42,85 \\
\hline 4 & $40-49$ & 8 & $22,85 \%$ \\
\hline \multicolumn{2}{|r|}{ Jumlah } & 35 & 100 \\
\hline
\end{tabular}

Tabel 4.0 diatas menunjukkan tanggapan siswa terhadap kegiatan pembelajaran keterampilan proses pada mata pelajaran geografi. Pada tabel diatas, interval kelas yang digunakan adalah 10, karena dengan demikian seluruh data akan tercakup dalam setiap interval kelas tersebut. Nilai interval kelas diperoleh dari hasil pembagian rentang skor dengan banyaknya kelas interval. Nilai rentang skor adalah 30 dan banyaknya kelas interval 3.

Berdasarkan tabel diatas dapat dilihat bahwa kecenderungan siswa menjawab pernyataan berada pada skor 30, hal tersebut dapat terlihat pada interval 30-39, itu berarti menunjukkan bahwa 
tanggapan siswa terhadap kegiatan pembelajaran geografi pada mata pelajaran geografi cukup bagus.

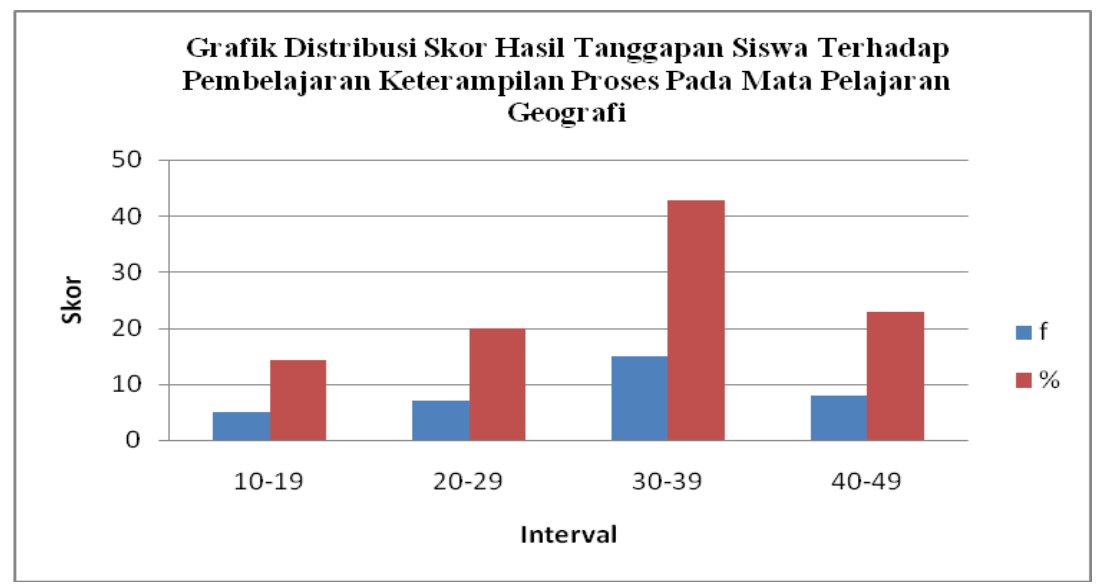

Skor tanggapan siswa terhadap pembelajaran keterampilan proses dapat dilihat pada grafik diatas. Untuk frekuensi tertinggi berada pada interval 30-39, dan frekuensi terendah berada pada interval 10-19. Perolehan skor rata-rata siswa menyatakan tanggapannya berada pada interval 3039 sebanyak $42,85 \%$. Setelah dihitung skor rata-rata siswa dalam menyatakan tanggapannya adalah 32, yang berarti siswa setuju terhadap pembelajaran keterampilan proses pada mata pelajaran geografi.

Guru geografi yang mengajar di kelas eksperimen pada penelitian ini berpendapat bahwa belajar geografi lebih baik langsung di lapangan dengan objek yang nyata, sehingga siswa dapat lebih memahami konsep maupun materi geografi yang sedang dipelajari. Selain itu juga, guru geografi di kelas eksperimen tersebut berpendapat bahwa pembelajaran geografi dengan menggunakan keterampilan proses cocok diterapkan pada mata pelajaran geografi dan memberikan peningkatan terhadap pemahaman serta penguasaan materi oleh para siswa. Kendala yang dihadapi para siswa dan guru geografi yaitu alat-alat observasi yang belum tersedia secara lengkap di sekolah, sehingga sebelum mengadakan observasi terlebih dahulu siswa dan guru geografi mencari dan menyediakan alat-alat untuk observasi secara swadaya.

\section{Data Hasil Penelitian}

Pada bab ini akan dikemukakan hasil penelitian dan pembahasannya yang berdasarkan tujuan penelitian. Data hasil penelitian diperoleh dari hasil tes awal (pre test) dan hasil tes akhir (post test) pada materi Atmosfer, baik pada kelas eksperimen maupun kelas kontrol.

Tes ini dibuat dalam bentuk tes objektif yang berupa pilihan ganda sebanyak 30 butir soal dengan skor total 30. Data yang diolah dalam penelitian ini meliputi data pre test, post test, dan gain. Adapun data-data yang diperoleh dalam penelitian ini adalah sebagai berikut:

\section{Data Pre Test}

\section{1) Data Pre Test Kelompok Eksperimen}

Data pre test siswa pada kelompok eksperimen diperoleh dari hasil tes siswa sebelum diadakan pembelajaran dengan menggunakan pendekatan keterampilan proses. Untuk mengetahui hasil data pre test pada kelompok eksperimen dapat dilihat pada tabel 4.1 berikut ini:

Tabel 4.1

Data Pre Test Kelompok Eksperimen

\begin{tabular}{|l|l|l|l|}
\hline No & Interval Kelas & Frekuensi & Frekuensi (\%) \\
\hline
\end{tabular}




\begin{tabular}{|c|c|c|c|}
\hline 1 & $14-15$ & 5 & $14,28 \%$ \\
2 & $16-17$ & 10 & $28,57 \%$ \\
3 & $18-19$ & 18 & $51,42 \%$ \\
4 & $20-21$ & 1 & $2,85 \%$ \\
5 & $22-23$ & 1 & $2,85 \%$ \\
\hline \multicolumn{2}{|c|}{ Jumlah } & 35 & 100 \\
\hline
\end{tabular}

Pada tabel diatas, interval kelas atau panjang kelas yang akan digunakan adalah 2, karena dengan demikian seluruh data akan tercakup dalam setiap interval kelas tersebut. Nilai interval kelas ini diperoleh dari hasil pembagian rentang skor dengan banyaknya kelas interval. Nilai rentang skor adalah 9 dan banyaknya kelas interval 6, seperti yang terlihat pada lampiaran 4.5 bagian $\mathrm{A}$.

Berdasarkan tabel diatas dapat dilihat bahwa interval skor terkecil adalah 14-15 ini menunjukkan bahwa nilai tersebut adalah kemampuan awal siswa kelompok eksperimen sebelum adanya pembelajaran dengan menggunakan pendekatan keterampilan proses. Untuk nilai pre test terbesar berada pada interval 22-23, jika dilihat dari kemampuan awal siswa maka nilai ini termasuk cukup bagus.

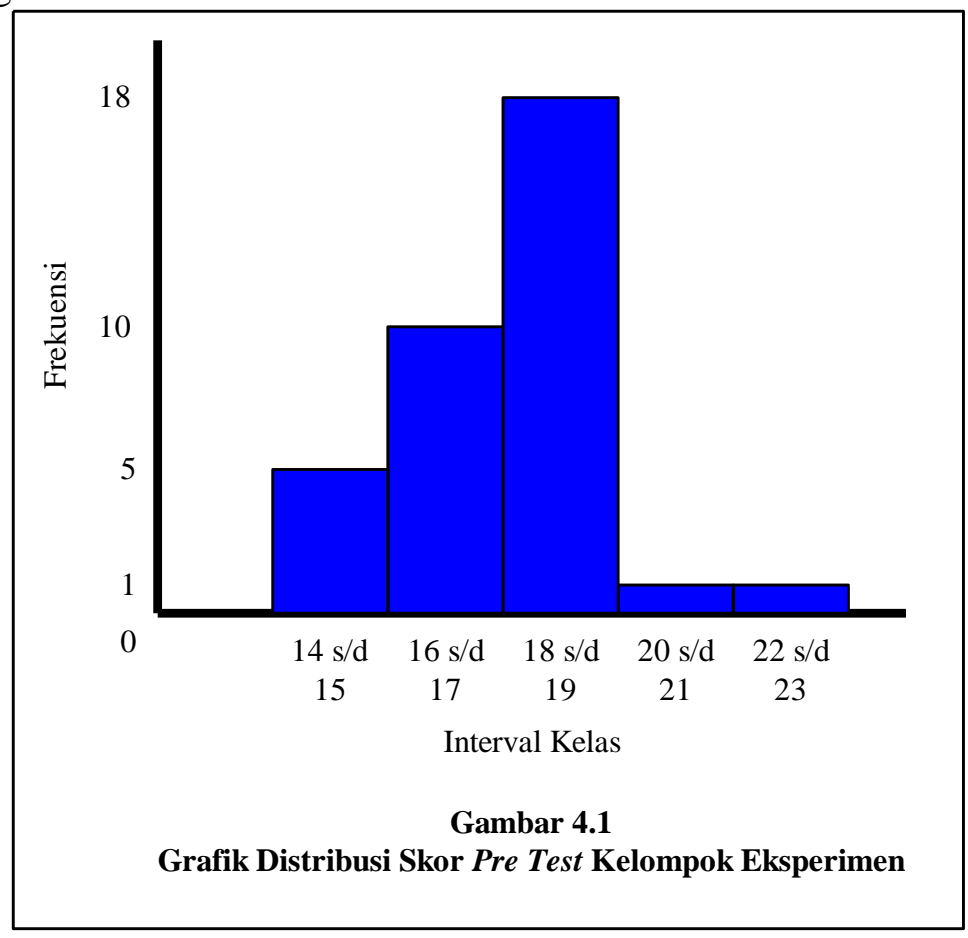

Nilai pre test pada kelompok eksperimen dapat dilihat pada gambar 4.1. Untuk frekuensi tertinggi berada pada interval 18-19, dan frekuensi terendah berada pada interval 20-21 dan 22-23. Perolehan skor rata-rata pada kelompok eksperimen berada pada interval 18-19 sebanyak 51,42\%. Setelah dihitung skor rata-rata pre test kelompok eksperimen adalah 17,52.

\section{2) Data Pre Test Kelompok Kontrol}

Data skor pre test siswa pada kelompok kontrol diperoleh dari hasil tes siswa sebelum diadakan pembelajaran dengan menggunakan metode ceramah bervariasi. Data skor pre test pada kelompok kontrol dapat dilihat pada tabel 4.2 dibawah ini: 
Tabel 4.2

Data Pre Test Kelompok Kontrol

\begin{tabular}{|c|c|c|c|}
\hline No & Interval Kelas & Frekuensi & Frekuensi (\%) \\
\hline 1 & $10-11$ & 2 & $5,71 \%$ \\
\hline 2 & $12-13$ & 7 & $20 \%$ \\
\hline 3 & $14-15$ & 10 & $28,57 \%$ \\
\hline 4 & $16-17$ & 12 & $34,28 \%$ \\
\hline 5 & 18-19 & 2 & $5,71 \%$ \\
\hline 6 & $20-21$ & 2 & $5,71 \%$ \\
\hline \multicolumn{2}{|r|}{ Jumlah } & 35 & 100 \\
\hline
\end{tabular}

Berdasarkan tabel diatas, dapat diketahui bahwa nilai skor terkecil yang dicapai siswa pada kelompok kontrol adalah 10-11 dan yang berjumlah 5,71\% dan nilai skor terbesar pada interval 20-21 sebanyak 5,71\%. Interval kelas atau panjang kelas pada tabel diatas adalah 2, agar seluruh data tercakup didalamnya dan nilai rentang skor adalah 10. Frekuensi skor tertinggi berada pada interval 16-17 yang berjumlah 34,28\% dan frekuensi skor terendah berada pada interval 10-11, 18-19, dan 20-21. Hal ini disebabkan karena siswa tidak mendapat materi Atmosfer sebelumnya. Nilai pre test pada kelompok kontrol dapat dilihat pada gambar 4.2

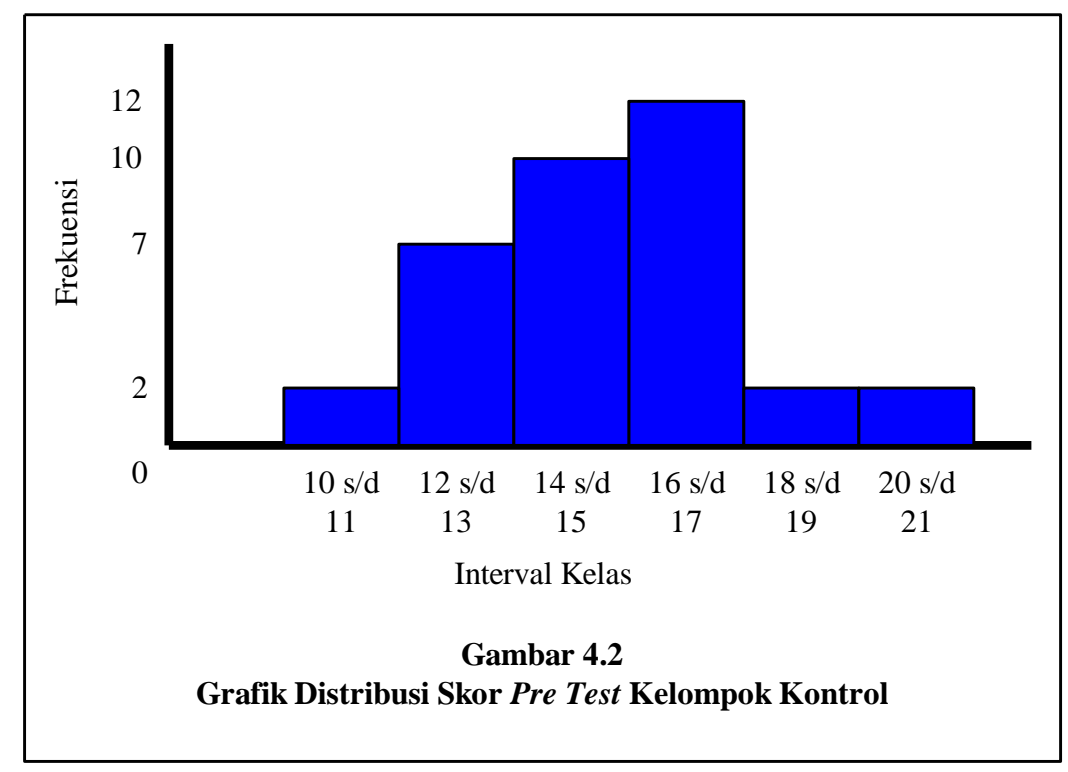

Perolehan skor rata-rata yang diperoleh pada kelompok kontrol berada pada pada interval 16-17 sebanyak 34,28\%. Adapun rata-rata skor yang diperoleh kelompok kontrol adalah 15,12. Perhitungan selengkapnya dapat dilihat pada lampiran 4.5 bagian B.

\section{3) Perbandingan Data Pre Test pada Kelompok Eksperimen dan Kelompok Kontrol}

Data skor pre test siswa pada kelompok eksperimen diperoleh sebelum diadakan kegiatan pembelajaran dengan menggunakan pendekatan keterampilan proses dan juga skor pre test kelompok kontrol diperoleh sebelum diadakan kegiatan pembelajaran dengan menggunakan ceramah bervariasi. 
Apabila dilihat berdasarkan tabel 4.1 dan tabel 4.2 maka terdapat perbandingan skor pre test terendah pada kelompok eksperimen berada pada interval 14-15 yaitu sebanyak 14,28\%, sedangkan pada kelompok kontrol berada pada interval 10-11 yaitu sebanyak 5,71\%. Untuk skor pre test tertinggi pada kelompok eksperimen berada pada interval 18-19 sebanyak 51,42\% sedangkan pada kelompok kontrol berada pada interval 16-17 sebanyak 34,28\%. Dengan demikian terdapat perbedaan data pre test pada kelompok eksperimen dan kelompok kontrol.

Berdasarkan hasil perhitungan, skor rata-rata pre test pada kelompok eksperimen adalah 17,52 sedangkan pada kelompok kontrol yaitu 15,21. Jika dibandingkan kedua skor rata-rata tersebut dapat diketahui bahwa skor rata-rata pre test pada eksperimen lebih tinggi daripada kelompok kontrol dengan selisih skor 2,31.

\section{Data Post Test}

\section{1) Data Post Test Kelompok Eksperimen}

Data post test siswa pada kelompok eksperimen diperoleh dari hasil tes siswa setelah diadakan pembelajaran dengan menggunakan pendekatan keterampilan proses. Untuk mengetahui hasil data post test pada kelompok eksperimen dapat dilihat pada tabel 4.3 berikut ini:

Tabel 4.3

Data Post Test Kelompok Eksperimen

\begin{tabular}{|c|c|c|c|}
\hline No & Interval Kelas & Frekuensi & Frekuensi (\%) \\
\hline 1 & 18-19 & 8 & $22,85 \%$ \\
\hline 2 & $20-21$ & 7 & $20 \%$ \\
\hline 3 & $22-23$ & 10 & $28,57 \%$ \\
\hline 4 & $24-25$ & 6 & $17,141 \%$ \\
\hline 5 & $26-27$ & 4 & $11,42 \%$ \\
\hline \multicolumn{2}{|r|}{ Jumlah } & 35 & 100 \\
\hline
\end{tabular}

Pada tabel diatas, interval kelas atau panjang kelas yang akan digunakan adalah 2, karena dengan demikian seluruh data akan tercakup dalam setiap interval kelas tersebut. Nilai interval kelas ini diperoleh dari hasil pembagian rentang skor dengan banyaknya kelas interval. Nilai rentang skor adalah 9 dan banyaknya kelas interval 6 .

Berdasarkan tabel diatas dapat dilihat bahwa nilai skor terkecil adalah 18-19. Untuk nilai post test terbesar berada pada interval 26-27. Untuk frekuensi tertinggi berada pada interval 2223, dan frekuensi terendah berada pada interval 26-27. Perolehan skor rata-rata pada kelompok eksperimen berada pada interval 22-23 sebanyak 28,57\%. Setelah dihitung skor rata-rata post test kelompok eksperimen adalah 21,3. Untuk nilai post test kelompok kontrol dapat dilihat pada gambar 4.3

Jika dibandingkan antara tabel 4.1 dan tabel 4.3, terlihat adanya perubahan skor siswa antara skor pre test dan skor post test. Hal tersebut dapat dilihat dari interval kelas terendah dan tertinggi pada skor post test. Selain itu juga, dilihat dari peningkatan rata-rata skor yang semula 17,52 menjadi 21,3. Adanya peningkatan hasil belajar ini dapat diperkirakan, karena pada saat post test siswa telah mendapat materi Atmosfer. 


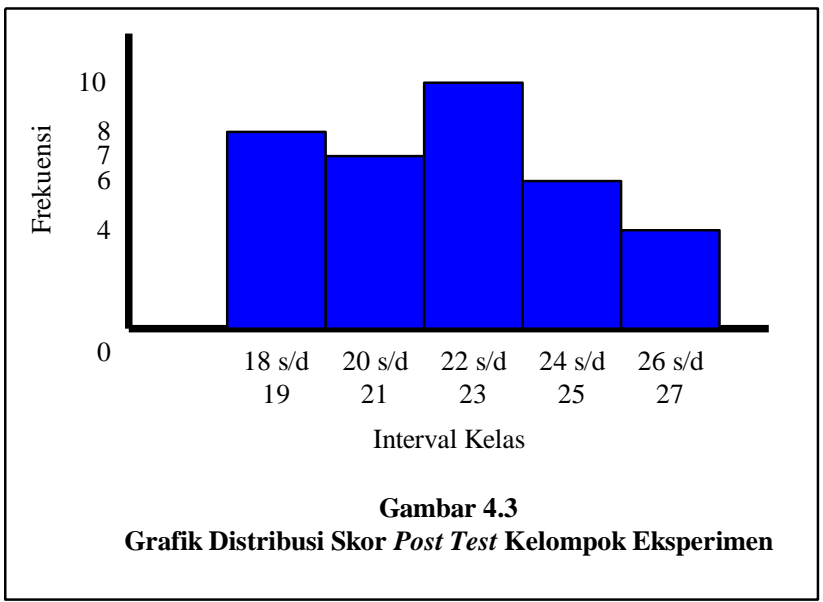

\section{2) Data Post Test Kelompok Kontrol}

Data skor post test siswa pada kelompok kontrol diperoleh dari hasil tes siswa setelah diadakan pembelajaran dengan menggunakan metode ceramah bervariasi. Data skor post test pada kelompok kontrol dapat dilihat pada tabel 4.4 dibawah ini:

Tabel 4.4

Data Post Test Kelompok Kontrol

\begin{tabular}{|c|c|c|c|}
\hline No & Interval Kelas & Frekuensi & Frekuensi (\%) \\
\hline 1 & $15-16$ & 4 & $11,42 \%$ \\
\hline 2 & $17-19$ & 10 & $28,57 \%$ \\
\hline 3 & $19-20$ & 5 & $14,28 \%$ \\
\hline 4 & $21-22$ & 11 & $31,42 \%$ \\
\hline 5 & $23-24$ & 3 & $8,57 \%$ \\
\hline 6 & $25-26$ & 2 & $5,71 \%$ \\
\hline \multicolumn{2}{|r|}{ Jumlah } & 35 & 100 \\
\hline
\end{tabular}

Berdasrakan tabel diatas, dapat diketahui bahwa nilai post test terkecil yang dicapai siswa pada kelompok kontrol berada pada interval 15-16 dan nilai post test terbesar berada pada interval 25-26 sebanyak. Interval kelas atau panjang kelas pada tabel diatas adalah 2, agar seluruh data tercakup didalamnya dan nilai rentang skor adalah 10. Frekuensi skor tertinggi berada pada interval 21-22 yang berjumlah 31,42\% dan frekuensi skor terendah berada pada interval 25-26 sebanyak 5,71\%. Nilai post test pada kelompok kontrol dapat dilihat pada gambar 4.4 


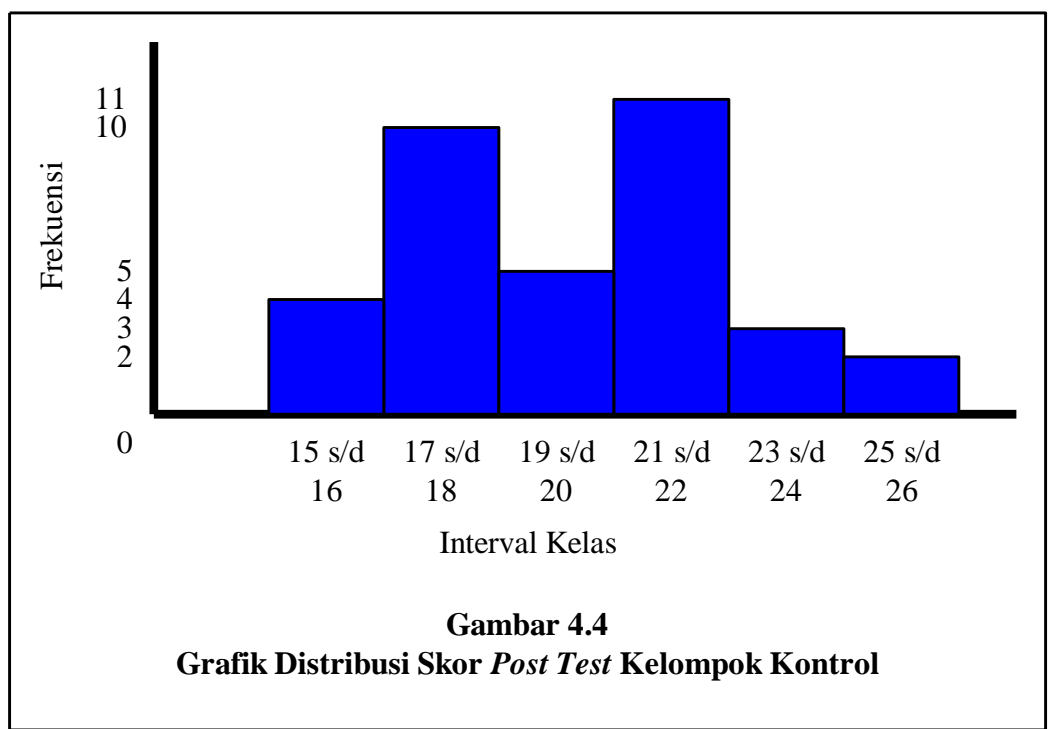

Jika dibandingkan antara tabel 4.4 dan tabel 4.2, terlihat adanya perubahan skor siswa antara skor pre test dan skor post test. Hal tersebut dapat dilihat dari interval kelas terendah dan tertinggi pada skor post test. Selain itu juga, dilihat dari peningkatan rata-rata skor yang semula 15,21 menjadi 19,78. Adanya peningkatan hasil belajar ini dapat diperkirakan, karena pada saat post test siswa telah mendapat materi Atmosfer. Perhitungan selengkapnya dapat dilihat pada lampiran 4.6 bagian $\mathrm{B}$.

\section{3) Perbandingan Data Post Test pada Kelompok Eksperimen dan Kelompok Kontrol}

Data skor pre test siswa pada kelompok eksperimen diperoleh sebelum diadakan kegiatan pembelajaran dengan menggunakan pendekatan keterampilan proses dan juga skor pre test kelompok kontrol diperoleh sebelum diadakan kegiatan pembelajaran dengan menggunakan metode ceramah bervariasi.

Apabila dilihat berdasarkan tabel 4.3 dan tabel 4.4 maka terdapat perbandingan skor post test terendah pada kelompok eksperimen berada pada interval 18-19 yaitu sebanyak 22,85\%, sedangkan pada kelompok kontrol berada pada interval 15-16 yaitu sebanyak $11,42 \%$. Untuk skor post test tertinggi pada kelompok eksperimen berada pada interval 26-27 sebanyak 11,42\% sedangkan pada kelompok kontrol berada pada interval 25-26 sebanyak 5,71\%. Dengan demikian terdapat perbedaan data post test pada kelompok eksperimen dan kelompok kontrol.

Berdasarkan hasil perhitungan, skor rata-rata post test pada kelompok eksperimen adalah 21,3 sedangkan pada kelompok kontrol yaitu 19,78. Jika dibandingkan kedua skor rata-rata tersebut dapat diketahui bahwa skor rata-rata post test pada eksperimen lebih tinggi daripada kelompok kontrol dengan selisih skor sebesar 1,52.

\section{Data Gain Pre Test dan Post Test}

\section{1) Data Gain Pre Test dan Post Test Kelompok Eksperimen}

Data gain pada kelompok eksperimen diperoleh dari hasil selisih post test dan pre test siswa pada kelompok eksperimen. Dengan kata lain, data gain pada kelompok eksperimen adalah hasil selisih tes siswa sebelum dan sesudah diadakannya kegiatan pembelajaran dengan pendekatan keterampilan proses. Data gain pre test dan post test pada kelompok eksperimen disajikan pada tabel 4.5 berikut ini: 
Tabel 4.5

Data Gain Pre Test dan Post Test Kelompok Eksperimen

\begin{tabular}{|c|c|c|c|}
\hline No & Interval Kelas & Frekuensi & Frekuensi (\%) \\
\hline 1 & $1-2$ & 8 & $22,85 \%$ \\
2 & $3-4$ & 13 & $37,14 \%$ \\
3 & $5-6$ & 5 & $14,28 \%$ \\
4 & $7-8$ & 7 & $20 \%$ \\
5 & $9-10$ & 2 & $5,71 \%$ \\
\hline \multicolumn{2}{|c|}{ Jumlah } & 35 & 100 \\
\hline
\end{tabular}

Interval kelas atau panjang kelas pada tabel diatas adalah 2, agar seluruh data tercakup didalamnya. Nilai ini diperoleh dari hasil pembagian antara rentang skor dengan banyaknya kelas interval. Nilai rentang skor adalah 10 dan banyaknya kelas interval adalah 5. Berdasarkan tabel diatas, skor gain terendah pada kelompok eksperimen berada pada interval kelas 1-2 sebesar $22,85 \%$ sedangkan gain tertinggi terdapat pada interval 3-4 sebanyak 37,14\%.

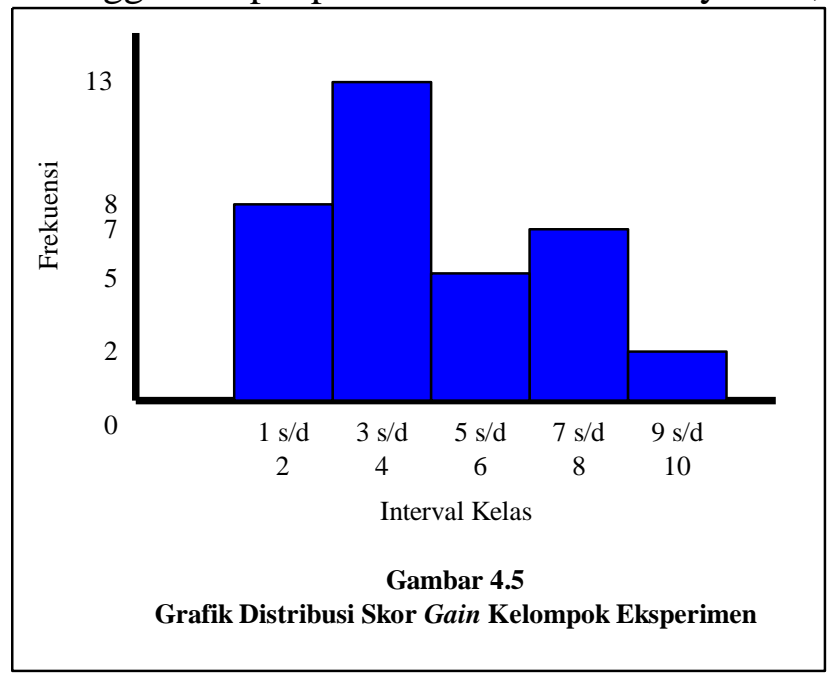

Nilai frekuensi skor tertinggi pada gambar di atas berada pada interval 3-4 dan interval kelas terendah berada pada interval 1-2. Adapun rata-rata skor gain kelompok eksperimen sebesar 4,47. Dari perolehan data tersebut bisa menunjukkan bahwa penggunaan pendekatan keterampilan proses pada kelompok eksperimen mempengaruhi hasil belajar siswa. Hasil perhitungan terdapat pada lampiran 4.7 bagian A.

\section{2) Data Gain Pre Test dan Post Test Kelompok Kontrol}

Data gain pada kelompok kontrol diperoleh dari hasil selisih post test dan pre test siswa pada kelompok kontrol. Dengan kata lain, data gain pada kelompok kontrol adalah hasil selisih tes siswa sebelum dan sesudah diadakannya kegiatan pembelajaran dengan menggunakan metode ceramah bervariasi. Data gain pre test dan post test pada kelompok kontrol disajikan pada tabel 4.6 berikut ini: 
Tabel 4.6

Data Gain Pre Test dan Post Test Kelompok Kontrol

\begin{tabular}{|c|c|c|c|}
\hline No & Interval Kelas & Frekuensi & Frekuensi (\%) \\
\hline 1 & $1-2$ & 8 & $22,85 \%$ \\
2 & $3-4$ & 12 & $34,28 \%$ \\
3 & $5-6$ & 9 & $25,71 \%$ \\
4 & $7-8$ & 6 & $17,14 \%$ \\
& & & \\
& & & \\
& & 35 & 100 \\
\hline \multicolumn{2}{|c|}{ Jumlah } & & \\
\hline
\end{tabular}

Sumber: Hasil Penelitian 2009

Interval kelas atau panjang kelas pada tabel diatas adalah 2, agar seluruh data tercakup didalamnya. Nilai ini diperoleh dari hasil pembagian antara rentang skor dengan banyaknya kelas interval. Nilai rentang skor adalah 8 dan banyaknya kelas interval adalah 4. Berdasarkan tabel diatas, skor gain terendah sebanyak 8 dan tertinggi yaitu sebanyak 6. Skor gain terendah pada kelompok kontrol berada pada interval kelas 1-2 sebesar 22,85\% sedangkan gain tertinggi terdapat pada interval 3-4 sebanyak 34,28\%. Nilai distribusi frekuensi skor gain kelompok kontrol dapat dilihat pada gambar 4.6 dengan nilai frekuensi tertinggi berada pada interval 3-4 sedangkan nilai frekuensi terendah berada pada interval 7-8.

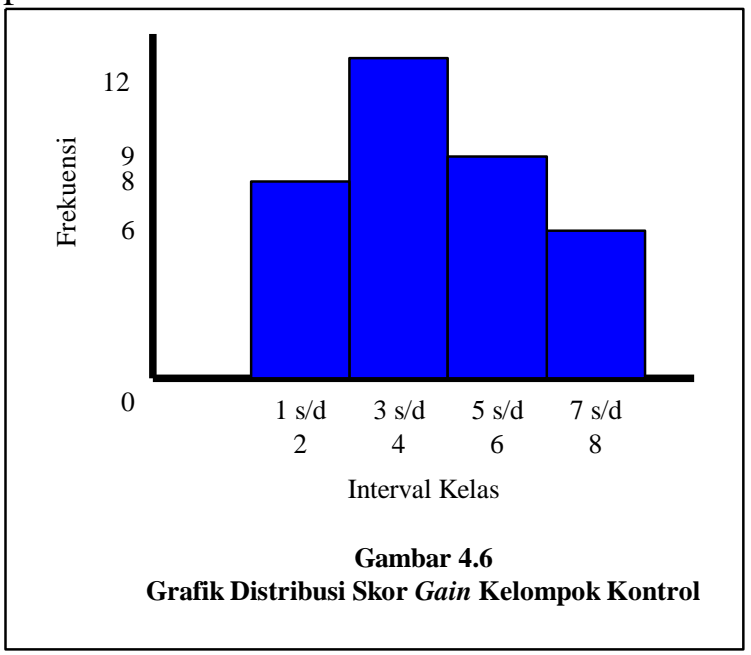

Adapun rata-rata skor gain kelompok kontrol sebesar 4,24. Dari perolehan data tersebut bisa menunjukkan bahwa penggunaan metode ceramah bervariasi pada kelompok kontrol mempengaruhi hasil belajar siswa. Hasil perhitungan terdapat pada lampiran 4.7 bagian B.

\section{3) Perbandingan Data Gain Pre Test dan Post Test pada Kelompok Eksperimen dan Kelompok Kontrol}

Data gain pre test dan post test merupakan selisih dari skor post test dan skor pre test. Berdasarkan tabel 4.5 dan tabel 4.6 dapat diketahui bahwa skor gain untuk kelompok eksperimen gain terendah berada pada interval 1-2 dengan frekuensi sebesar 22,85\% sedangkan untuk 
kelompok kontrol gain terendah juga sama berada pada interval 1-2 dengan frekuensi sebesar 22,85\%. Gain tertinggi pada kelompok eksperimen memiliki interval 9-10 dengan frekuensi 5,71\% sedangkan untuk gain pada kelompok kontrol berada pada interval 7-8 dengan frekuensi sebesar $17,14 \%$.

Untuk gain yang memiliki frekuensi terbanyak pada kelompok eksperimen berada pada interval 3-4 sebesar 37,14\% sedangkan untuk kelompok kontrol terdapat pada interval 3-4 sebanyak 34,28\%. Berdasarkan hasil perhitungan rata-rata gain untuk kelompok eksperimen adalah 4,47 dan rata-rata gain pada kelompok kontrol adalah 4,24. Dengan demikian perbandingan data gain kelompok eksperimen lebih tinggi daripada kelompok kontrol.

\section{Analisis Data}

Analisis data dilakukan untuk mengetahui pengaruh penggunaan pendekatan keterampilan proses terhadap prestasi belajar siswa pada kelompok eksperimen dan penggunaan metode ceramah bervariasi terhadap prestasi belajar siswa. Untuk itu maka dilakukan uji statistic terhadap data yang telah diperoleh. Adapun uji statistik tersebut adalah sebagai berikut:

\section{a. Uji Normalitas Data Pre Test Kelompok Eksperimen dan Kelompok Kontrol}

Pengujian normalitas data pre test pada kelompok eksperimen dan kelompok kontrol dilakukan dengan menggunakan uji chi kuadrat $\left(\mathrm{X}^{2}\right)$. Pengujian ini dilakukan pada taraf signifikansi 5\% $(\alpha=0,05)$ dengan derajat kebebasan $\mathrm{dK}=\mathrm{K}-3$, hasil uji chi kuadrat adalah sebagai berikut:

Tabel 4.7

Uji Normalitas Data Pre Test

Kelompok Eksperimen dan Kelompok Kontrol

\begin{tabular}{|l|c|c|c|}
\hline \multicolumn{1}{|c|}{ Kelompok } & $\mathrm{X}^{2}$ Hitung & $\mathrm{X}^{2}$ Tabel & Kriteria \\
\hline Kelompok Eksperimen & 6,51 & 7,81 & Normal \\
Kelompok Kontrol & 4,28 & 7,81 & Normal \\
\hline
\end{tabular}

Sumber: Hasil Penelitian 2009

Berdasarkan tabel 4.7 dapat diketahui bahwa skor pre test baik pada kelompok kontrol sama-sama berdistribusi normal, karena jika dibandingkan antara $\mathrm{X}^{2}$ Hitung dan $\mathrm{X}^{2}$ Tabel pada kedua kelompok tersebut memenuhi ketentuan $\mathrm{X}^{2}$ Hitung $<\mathrm{X}^{2}$ Tabel. Perhitungan uji normalitas pre test pada kelompok eksperimen dan kelompok kontrol selengkapnya dapat dilihat pada lampiran 4.5.

\section{b. Uji Normalitas Data Post Test Kelompok Eksperimen dan Kelompok Kontrol}

Untuk menguji normalitas data post test dilakukan dengan menggunakan uji chi kuadrat $\left(\mathrm{X}^{2}\right)$ seperti halnya uji normalitas data pre test. Adapun hasil uji normalitas data post test pada kelompok eksperimen dan kelompok kontrol adalah sebagai berikut:

Tabel 4.8

Uji Normalitas Data Post Test

Kelompok Eksperimen dan Kelompok Kontrol

\begin{tabular}{|c|c|c|c|}
\hline Kelompok & $\mathrm{X}^{\mathbf{2}}$ Hitung & $\mathrm{X}^{\mathbf{2}}$ Tabel & Kriteria \\
\hline Kelompok Eksperimen & 5,9 & 7,81 & Normal \\
Kelompok Kontrol & 6,28 & 7,81 & Normal \\
\hline
\end{tabular}


Berdasarkan tabel 4.8 dapat diketahui bahwa skor post test baik pada kelompok kontrol sama-sama berdistribusi normal, karena jika dibandingkan antara $\mathrm{X}^{2}$ Hitung dan $\mathrm{X}^{2}$ Tabel pada kedua kelompok tersebut memenuhi ketentuan $\mathrm{X}^{2}$ Hitung $<\mathrm{X}^{2}$ Tabel . Perhitungan uji normalitas post test pada kelompok eksperimen dan kelompok kontrol selengkapnya dapat dilihat pada lampiran 4.6.

\section{c. Uji Normalitas Data Gain Kelompok Eksperimen dan Kelompok Kontrol}

Hasil uji normalitas kelompok gain kelompok eksperimen dan kelompok kontrol juga menggunakan pengujian chi kuadrat $\left(\mathrm{X}^{2}\right)$, hasilnya terdapat pada tabel berikut ini:

Tabel 4.9

Uji Normalitas Data Gain

Kelompok Eksperimen dan Kelompok Kontrol

\begin{tabular}{|l|c|c|c|}
\hline \multicolumn{1}{|c|}{ Kelompok } & $\mathrm{X}^{\mathbf{2}}$ Hitung & $\mathrm{X}^{\mathbf{2}}$ Tabel & Kriteria \\
\hline Kelompok Eksperimen & 6,26 & 7,81 & Normal \\
Kelompok Kontrol & 5,15 & 7,81 & Normal \\
\hline
\end{tabular}

Berdasarkan tabel 4.9 dapat diketahui bahwa uji normalitas data gain kelompok eksperimen dan kelompok kontrol sama-sama berdistribusi normal, karena jika dibandingkan antara $\mathrm{X}^{2}$ Hitung dan $\mathrm{X}^{2}$ Tabel pada kedua kelompok tersebut memenuhi ketentuan $\mathrm{X}^{2}$ Hitung $<\mathrm{X}^{2}$ Tabel . Perhitungan uji normalitas data gain pada kelompok eksperimen dan kelompok kontrol selengkapnya dapat dilihat pada lampiran 4.7.

\section{d. Uji Homogenitas Data Pre Test dan Post Test Kelompok Eksperimen}

Setelah melakukan uji normalitas dan diperoleh kesimpulan bahwa kedua kelompok berdistribusi normal, maka langkah selanjutnya adalah dengan melakukan uji homogenitas varians dengan melakukan uji-F. Pengujian homogenitas varians ini dimaksudkan untuk menguji apakah varians dari kedua kelompok antara pre test, post test, dan gain bersifat homogen atau tidak. Hasil uji homogenitas pre test dan post test pada kelompok eksperimen dapat dilihat pada tabel 4.10 berikut ini:

Tabel 4.10

Uji Homogenitas Kelompok Eksperimen

\begin{tabular}{|l|c|c|c|c|}
\hline \multicolumn{1}{|c|}{ Data yang Diuji } & Varians & $\mathrm{F}_{\text {Hitung }}$ & $\mathrm{F}_{\text {Tabel }}$ & Kriteria \\
\hline Pre Test & 3,21 & 1,61 & 1,77 & Homogen \\
Post Test & 5,2 & 1,61 & 1,77 & Homogen \\
\hline
\end{tabular}

Sumber: Hasil Penelitian 2009

Dari tabel diatas dapat dismpulkan bahwa varians data pre test dan post test kelompok eksperimen bersifat homogen, karena memenuhi ketentuan $\mathrm{F}_{\text {Hitung }}<\mathrm{F}_{\text {Tabel }}$. Hasil perhitungan tercantum pada lampiran 4.8 bagian $\mathrm{A}$.

\section{e. Uji Homogenitas Data Pre Test dan Post Test Kelompok Kontrol}

Dibawah ini merupakan data hasil uji homogenitas data pre test dan post test kelompok kontrol terdapat pada tabel 4.11: 
Tabel 4.11

Uji Homogenitas Kelompok Kontrol

\begin{tabular}{|l|c|c|c|c|}
\hline \multicolumn{1}{|c|}{ Data yang Diuji } & Varians & $\mathrm{F}_{\text {Hitung }}$ & $\mathrm{F}_{\text {Tabel }}$ & Kriteria \\
\hline Pre Test & 5,82 & 1,34 & 1,77 & Homogen \\
Post Test & 7,8 & 1,34 & 1,77 & Homogen \\
\hline
\end{tabular}

Dari tabel diatas dapat disimpulkan bahwa varians data pre test dan post test kelompok eksperimen bersifat homogen, karena memenuhi ketentuan $\mathrm{F}_{\text {Hitung }}<\mathrm{F}_{\text {Tabel }}$. Dimana nilai $\mathrm{F}_{\text {Hitung }}$ adalah 1,34 dan $\mathrm{F}_{\text {Tabel }}$ adalah 1,77. Dari kedua data tersebut terlihat bahwa nilai $\mathrm{F}_{\text {Hitung }}$ lebih kecil daripada $\mathrm{F}_{\text {Tabel }}$ maka kriterianya adalah homogen. Hasil perhitungan tercantum pada lampiran 4.8 bagian $\mathrm{B}$.

\section{f. Uji Homogenitas Data Gain Kelompok Eksperimen dan Kelompok Kontrol}

Dibawah ini adalah data hasil uji homogenitas gain pada kelompok eksperimen dan kelompok kontrol dapat dilihat pada tabel 4.12 dibawah ini:

Tabel 4.12

Uji Homogenitas Gain Kelompok Eksperimen dan Kelompok Kontrol

\begin{tabular}{|l|c|c|c|c|}
\hline \multicolumn{1}{|c|}{ Kelompok } & Varians & $\mathrm{F}_{\text {Hitung }}$ & $\mathrm{F}_{\text {Tabel }}$ & Kriteria \\
\hline Kelompok Eksperimen & 6 & 1,41 & 1,77 & Homogen \\
Kelompok Kontrol & 4,25 & 1,41 & 1,77 & Homogen \\
\hline
\end{tabular}

Berdasarkan tabel diatas dapat diketahui bahwa $\mathrm{F}_{\text {Hitung }}$ gain pada kedua kelompok tersebut adalah 1,41 sedangkan $\mathrm{F}_{\text {Tabel }}$ dengan taraf signifikansi 5\% $(\dot{\alpha}=0,05)$ dengan derajat $d K=N-1$ bernilai 1,77 maka data gain kedua kelompok tersebut berada dalam kriteria homogen. Perhitungan selengkapnya terdapat pada lampiran 4.8 bagian $\mathrm{C}$.

\section{g. Uji Hipotesis Kelompok Eksperimen}

Setelah data hasil penelitian dinyatakan berdistribusi normal dan homogen, maka langkah selanjutnya adalah melakukan uji hipotesis dengan menggunakan uji-t. Uji hipotesis dilakukan untuk melihat pengaruh penggunaan pendekatan keterampilan proses terhadap prestasi belajar siswa. Berikut ini akan disajikan tabel mengenai uji hipotesis pada kelompok eksperimen.

Tabel 4.13

Hasil Uji Hipotesis Kelompok Eksperimen

\begin{tabular}{|l|c|c|c|c|l|}
\hline Data yang Diuji & Varians & Rata-Rata & $\mathrm{t}_{\text {Hitung }}$ & $\mathrm{t}_{\text {Tabel }}$ & \multicolumn{1}{|c|}{ Kriteria } \\
\hline Pre Test & 3,21 & 17,52 & 7,91 & 1,997 & $\mathrm{H}_{1}:$ diterima \\
Post Test & 5,2 & 21,3 & 7,91 & 1,997 & Ho : ditolak \\
\hline
\end{tabular}

Sumber : Hasil Penelitian 2009

Berdasarkan tabel 4.13, dapat diketahui bahwa $\mathrm{t}_{\text {Hitung }}$ pada kelompok eksperimen baik post test maupun pre test adalah 7,91. Untuk mengetahui apakah hipotesis nol dan hipotesis alternatif diterima atau ditolak, maka $t_{\text {Hitung }}$ harus dibandingkan dengan $\mathrm{t}_{\text {Tabel }}$ dengan ketentuan jika $\mathrm{t}_{\text {Hitung }}>$ $\mathrm{t}_{\text {Tabel }}$ maka Ho : ditolak dan sebaliknya jika $\mathrm{t}_{\text {Hitung }}<\mathrm{t}_{\text {Tabel }}$ maka $\mathrm{H}_{1}$ : diterima. 
Setelah dilakukan perhitungan $\mathrm{t}_{\text {Tabel }}$ pada taraf signifikansi 5\% ( $\left.\dot{\alpha}=0,05\right)$ dan $d K=N_{l}+$ $N_{2}-2$, diproleh nilai $t_{T a b e l}$ sebesar 1,997. Nilai $t_{\text {Tabel }}$ ini selanjutnya dibandingkan dengan $\mathrm{t}_{\text {Hitung }}$. Dan ternyata diketahui bahwa $\mathrm{t}_{\text {Hitung }}>\mathrm{t}_{\text {Tabel. }}$. Hal ini berarti $\mathrm{H}_{1}$ diterima dan Ho ditolak. Penggunaan pendekatan keterampilan proses pada prestasi belajar siswa untuk rata-rata nilai pre test kelompok eksperimen sebesar 17,52 sedangkan untuk rata-rata nilai post test sebesar 21,3. Maka selisih hasil belajar siswa yang menggunakan pendekatan keterampilan proses adalah sebesar 3,78. Dengan demikian, dapat disimpulkan bahwa terdapat perbedaan yang signifikan antara hasil belajar siswa kelompok eksperimen sesudah dan sebelum pembelajaran menggunakan pendekatan keterampilan proses. Perhitungan selengkapnya dapat dilihat pada lampiran 4.9 bagian 1 .

\section{h. Uji Hipotesis Kelompok Kontrol}

Setelah data hasil penelitian, data kelompok kontrol dinyatakan berdistribusi normal dan homogen, maka langkah selanjutnya adalah melakukan uji hipotesis dengan menggunakan uji-t. Uji hipotesis dilakukan untuk melihat pengaruh penggunaan metode ceramah bervariasi terhadap prestasi belajar siswa. Berikut ini akan disajikan tabel mengenai uji hipotesis pada kelompok kontrol.

Tabel 4.14

Hasil Uji Hipotesis Kelompok Kontrol

\begin{tabular}{|l|c|c|c|c|l|}
\hline Data yang Diuji & Varians & Rata-Rata & $\mathrm{t}_{\text {Hitung }}$ & $\mathrm{t}_{\text {Tabel }}$ & \multicolumn{1}{|c|}{ Kriteria } \\
\hline Pre Test & 5,82 & 15,12 & 7,51 & 1,997 & $\mathrm{H}_{1}:$ diterima \\
Post Test & 7,8 & 19,78 & 7,51 & 1,997 & Ho : ditolak \\
\hline
\end{tabular}

Sumber : Hasil Penelitian 2009

Berdasarkan tabel 4.14, dapat diketahui bahwa $\mathrm{t}_{\text {Hitung }}$ pada kelompok kontrol baik post test maupun pre test adalah 7,51. Untuk mengetahui apakah hipotesis nol dan hipotesis alternatif diterima atau ditolak, maka $\mathrm{t}_{\text {Hitung }}$ harus dibandingkan dengan $\mathrm{t}_{\text {Tabel }}$ dengan ketentuan jika $\mathrm{t}_{\text {Hitung }}>$ $\mathrm{t}_{\text {Tabel }}$ maka Ho : ditolak dan sebaliknya jika $\mathrm{t}_{\text {Hitung }}<\mathrm{t}_{\text {Tabel }}$ maka $\mathrm{H}_{1}$ : diterima.

Setelah dilakukan perhitungan $\mathrm{t}_{\text {Tabel }}$ pada taraf signifikansi $5 \%(\dot{\alpha}=0,05)$ dan $d K=N_{1}+$ $N_{2}-2$, diperoleh nilai $t_{T a b e l}$ sebesar 1,997 . Nilai $t_{\text {Tabel }}$ ini selanjutnya dibandingkan dengan $\mathrm{t}_{\text {Hitung. }}$. Dan ternyata diketahui bahwa $\mathrm{t}_{\text {Hitung }}>\mathrm{t}_{\text {Tabel. }}$. Hal ini berarti $\mathrm{H}_{1}$ diterima dan Ho ditolak. Penggunaan metode ceramah bervariasi pada prestasi belajar siswa untuk rata-rata nilai pre test kelompok kontrol sebesar 15,12 sedangkan untuk rata-rata nilai post test sebesar 19,78. Maka selisih hasil belajar siswa yang menggunakan metode ceramah bervariasi adalah sebesar 4,66. Dengan demikian, dapat disimpulkan bahwa terdapat perbedaan yang signifikan antara hasil belajar siswa kelompok kontrol sesudah dan sebelum pembelajaran menggunakan metode ceramah bervariasi. Perhitungan selengkapnya dapat dilihat pada lampiran 4.9 bagian 2 .

i. Uji Hipotesis Gain, Pre Test, dan Post Test Kelompok Eksperimen dan Kelompok Kontrol.

Langkah selanjutnya setelah mengetahui hipotesis kelompok eksperimen dan kelompok kontrol menggunakan uji-t adalah menghitung gain dari kedua kelompok yang terdapat pada tabel 4.15 dibawah ini: 
Tabel 4.15

Hasil Uji Hipotesis Gain Kelompok Eksperimen dan Kelompok Kontrol

\begin{tabular}{|l|l|l|l|l|l|}
\hline \multicolumn{1}{|c|}{ Data yang Diuji } & Varians & Rata-Rata & $\mathfrak{t}_{\text {Hitung }}$ & $\mathfrak{t}_{\text {Tabel }}$ & Kriteria \\
\hline Gain kelompok eksperimen & 6 & 4,47 & 0,42 & 1,997 & $\mathrm{H}_{1}:$ ditolak \\
Gain kelompok control & 4,25 & 4,24 & 0,42 & 1,997 & \\
& & & & & Ho : diterima \\
\hline
\end{tabular}

Berdasarkan tabel 4.15, sumber penelitian adalah hasil penelitian tahun 2009 dan dapat diketahui bahwa nilai rata-rata gain pada kelompok eksperimen adalah 4,47 dan pada kelompok kontrol adalah 4,24. Dengan demikian perbandingan tersebut menunjukkan bahwa gain kelompok eksperimen lebih tinggi daripada kelompok kontrol. Hal ini berarti bahwa pendekatan keterampilan proses unggul dibandingkan dengan metode ceramah bervariasi.

Setelah dilakukan perhitungan $\mathrm{t}_{\text {Tabel }}$ pada taraf signifikansi $5 \%(\dot{\alpha}=0,05)$ dan $d K=N_{1}+$ $N_{2}-2$, diperoleh nilai $\mathrm{t}_{\text {Tabel }}$ sebesar 1,997 . Nilai $\mathrm{t}_{\text {Tabel }}$ ini selanjutnya dibandingkan dengan $\mathrm{t}_{\text {Hitung. }}$. Dan ternyata diketahui bahwa $\mathrm{t}_{\text {Hitung }}<\mathrm{t}_{\text {Tabel }}$. Hal ini berarti $\mathrm{H}_{1}$ ditolak dan Ho diterima. Dengan kriteria demikian dapat disimpulkan bahwa tidak terdapat perbedaan yang signifikan antara hasil belajar siswa pada kelompok eksperimen yang menggunakan pendekatan ketrampilan proses dengan hasil belajar siswa pada kelompok kontrol yang menggunakan metode ceramah bervariasi. Hal tersebut dikarenakan dari perbedaan rata-rata gain kelompok eksperimen dan kelompok kontrol yang memiliki selisih hanya sebesar 0,23. Perhitungan selengkapnya dapat dilihat pada lampiran 4.9 bagian 3 .

\section{F. Pembahasan}

Berdasarkan hasil penelitian dan analisis data, dapat diketahui bhawa terdapat pengaruh yang signifikan terhadap prestasi belajar siswa pada materi Atmosfer yang menggunakan pendekatan keterampilan proses pada kelompok eksperimen dan metode ceramah bervariasi pada kelompok kontrol. Nilai rata-rata pre test untuk kelompok eksperimen adalah 17,52 dan untuk kelompok kontrol adalah 15,12, nilai ini diperoleh sebelum kedua kelompok tersebut mendapatkan materi dan merupakan kemampuan awal siswa yang cukup baik.

Setelah mendapatkan materi dengan menggunakan pendekatan keterampilan proses untuk kelompok eksperimen dan metode ceramah bervariasi untuk kelompok kontrol, skor siswa atau nilai post test menjadi 21,3 untuk kelompok eksperimen dan 19,78 untuk kelompok kontrol. Dengan demikian skor terbesar terdapat pada kelompok eksperimen yang dilihat dari adanya peningkatan hasil tes. Namun, untuk menjawab hipotesis yang diajukan membutuhkan uji hipotesis secara statistik.

Bila bila dihitung rata-rata gain dari kedua kelompok tersebut, kelompok eksperimen mempunyai gain 4,74 dan kelompok kontrol mempunyai gain 4,24. Maka berdasarkan data gain tersebut dapat dikatakan bahwa pendekatan keterampilan proses ternyata tidak lebih efektif untuk meningkatkan hasil belajar siswa.

Penerapan pendekatan keterampilan proses pada mata pelajaran Geografi dengan materi atmosfer merupakan hal yang baru bagi siswa pada kelompok eksperimen, karena sebelumnya siswa lebih banyak mendapatkan materi dengan ceramah guru. Berdasarkan hasil penelitian, pendekatan keterampilan proses memberikan pengalaman belajar yang baru bagi siswa serta dapat meningkatkan prestasi belajar siswa. Hal ini dikarenakan pendekatan keterampilan proses merupakan suatu strategi yang berpusat pada siswa dimana kelompok-kelompok siswa dihadapkan pada gejala di atmosfer untuk diamati dan mencari jawaban atas pertanyaan-pertanyaan hasil 
analisis pengamatan yang telah dilakukan, sehingga siswa termotivasi untuk memahami materi pelajaran bersama dengan teman satu kelompoknya.

Kegiatan pembelajaran yang menggunakan pendekatan keterampilan proses ini ternyata membuat siswa lebih memahami materi yang sedang dipelajari. Pada waktu proses mengamati siswa dapat lebih mengerti dengan melihat dan merasakan, unsur-unsur cuaca dan iklim, selain itu juga mereka dapat langsung menganalisis keadaan cuaca dan iklim. Setelah siswa melakukan pengamatan pada objeknya secara langsung, seluruh siswa dan kelompoknya dapat mengemukakan pertanyaan-pertanyaan berdasrkan gejala atmosfer yang dianalisis, yang sebelumnya siswa tidak begitu memperhatikan terhadap gejala-gejala atmosfer yang mempengaruhi kehidupan di bumi. Selain beberapa pertanyaan yang mereka ajukan, siswa tersebut beserta kelompoknya dapat mengemukakan dugaan awal dari suatu gejala yang terjadi di Atmosfer. Seluruh peningkatan kemampuan belajar tersebut merupakan hasil dari kegiatan belajar dengan menggunakan pendekatan keterampilan proses. Siswa dapat memanfaatkan dengan baik inderanya dalam kegiatan pembelajaran yang berdampak baik terhadap pemikiran secara ilmiah serta prestasi belajar mereka.

Pada penelitian ini dilakukan analisis data untuk menguji normalitas dan homogenitas data serta menguji hipotesis. Berdasarkan perhitungan statistika didapat data bahwa hasil penelitian penelitian berdistribusi normal dan homogen. Selanjutnya dilakukan uji hipotesis atau uji-t yang diperoleh dari hasil $t_{\text {Hitung }}>\mathrm{t}_{\text {Tabel }}$ pada kelompok eksperimen dan kelompok kontrol. Hal ini berarti Ho ditolak dan $\mathrm{H}_{1}$ diterima. Dengan demikian dapat disimpulkan bahwa terdapat peningkatan hasil belajar siswa antara hasil pre test dan post test pada kelompok eksperimen dan kelompok kontrol.

Dari adanya peningkatan prestasi belajar siswa antara hasil pre test dan post test pada kelompok eksperimen maupun kelompok kontrol, dapat menunjukkan bahwa pendekatan keterampilan proses memberikan pengaruh terhadap hasil belajar siswa kelas X SMAN 11 Kota Bandung. Selain itu pendekatan ini juga melibatkan siswa secara aktif. Pembelajaran menggunakan pendekatan keterampilan proses berorientasi pada pengolahan data hasil pengamatan untuk melatih siswa memiliki kemampuan berpikir untuk menemukan dan mencari suatu pengetahuan secara ilmiah.

Anna Poedjiadi menyatakan bahwa pendekatan keterampilan proses ialah " Terampil memproses perolehan menggunakan proses-proses mental, termasuk keterampilan psikomotor yang sebenarnya didasari oleh kegiatan mental seseorang. Keterampilan-keterampilan dasar yang dimaksud antara lain adalah mengobservasi, menghitung, mengukur, mengklasifikasi, membuat hipotesis, dan lain-lain".

Proses pembelajaran ini dimulai dari objek nyata atau objek sebenarnya dengan menggunakan pengalaman langsung, sehingga siswa diharapkan terjun dalam kegiatan belajar mengajar yang lebih realistis, dan juga diajak, dilatih, dan dibiasakan melakukan observasi langsung dan membuat kesimpulan sendiri. Dengan demikian, keterampilan proses menekankan pada bagaimana siswa belajar mengelola perolehannya sendiri, sehingga dipahami dan dapat dipakai sebagai bekal untuk memenuhi kebutuhan dalam kehidupannya dimasyarakat.

Penelitian ini telah berhasil menjawab pertanyaan yang diajukan yang terdapat dalam rumusan masalah, yaitu mengungkapkan keberhasilan pembelajaran dengan menggunakan pendekatan keterampilan proses. Penelitian tersebut dapat memperlihatkan bahwa pembelajaran dengan menggunakan pendekatan keterampilan proses menghasilkan hasil belajar yang lebih baik dibandingkan dengan metode ceramah bervariasi yang biasa dipakai oleh guru mata pelajaran geografi di SMAN 11 Bandung. Dengan adanya kegiatan pembelajaran dengan menggunakan 
keterampilan proses, siswa dapat meningkatkan proses berpikir secara ilmiah dan hasil belajarnya pun memberikan hasil yang baik.

Namun peneliti menyadari bahwa pelaksanaan pembelajaran dengan menggunakan pendekatan keterampilan proses masih kurang optimal masih terdapat kelemahan, hal tersebut dikarenakan oleh sumberdaya manusia yang masih kurang. Guru dituntut untuk dapat memotivasi siswa untuk dapat belajar bukan hanya menguasai materi saja. Kelemahan yang terdapat dalam penelitian ini yaitu lemahnya instrumen tes yang berupa tes objektif. Pada instrumen tersebut kelemahannya ialah kurang tercapainya komposisi ranah pada penyusunan setiap soal sehingga instrumen yang diujikan tidak dapat membedakan kemampuan antara siswa yang mampu menjawab soal dengan baik dengan siswa yang tidak mampu menjawab soal dengan baik. Tujuan belajar yang sebenarnya adalah untuk memperoleh pengetahuan dengan menggunakan suatu cara yang dapat melatih kemampuan intelektual siswa dan memotivasi kemampuan siswa.

Dengan menggunakan pendekatan keterampilan proses dalam pembelajaran, siswa tidak hanya menjadi penghapal materi saja tetapi dapat membuat para siswa untuk observasi langsung dan membuat kesimpulan sendiri dalam melakukan pencarian konsep materi yang dipelajari.

\section{KESIMPULAN DAN REKOMENDASI}

\section{Kesimpulan}

Berdasarkan hasil penelitian yang dilakukan, pengolahan data, serta analisis data, terdapat beberapa kesimpulan sebagai berikut:

1. Prestasi belajar siswa pada kelompok eksperimen dan kelompok kontrol sebelum mendapatkan materi atmosfer dan penggunaan pendekatan keterampilan proses dapat dikatakan cukup baik, hal itu terlihat dari rata-rata hasil pre test kedua kelompok tersebut. Rata-rata pre test untuk kelompok eksperimen 17,52 dan rata-rata pre test kelompok kontrol sebesar 15,12

2. Setelah mendapatkan materi Atmosfer dan setelah mendapatkan pembelajaran dengan pendekatan keterampilan proses untuk kelompok eksperimen serta metode ceramah bervariasi untuk kelompok kontrol, terdapat peningkatan prestasi belajar yang lebih baik, berikut adalah kesimpulan selengkapnya:

\section{a. $\quad 76$}

Terdapat peningkatan hasil belajar siswa yang signifikan antara hasil pre test dan post test pada kelompok eksperimen yang menggunakan pembelajaran dengan pendekatan keterampilan proses pada materi Atmosfer. Hal ini berarti prestasi belajar siswa yang berupa nilai antara sebelum dan sesudah kegiatan pembelajaran mengalami perubahan. Perubahan prestasi belajar siswa ini terlihat dari skor rata-rata yang diperoleh siswa setelah pembelajaran mengalami peningkatan menjadi 21,3. Hal tersebut dapat diketahui dari hasil uji hipotesis dengan taraf siginifikansi $5 \%$.

b. Terdapat peningkatan hasil yang signifikan antara hasil pre test dan post test pada kelompok kontrol yang menggunakan pembelajaran dengan metode ceramah bervariasi. Perubahan prestasi belajar siswa ini terlihat dari skor rata-rata yang diperoleh siswa setelah pembelajaran mengalami peningkatan menjadi 19,78. Hal tersebut dapat diketahui dari hasil uji hipotesis dengan taraf siginifikansi $5 \%$. 
c. Tidak terdapat perbedaan prestasi belajar siswa yang signifikan antara kelompok eksperimen dan kelompok kontrol pada materi Atmosfer. Dimana kelompok eksperimen menggunakan pembelajaran dengan pendekatan keterampilan proses sedangkan kelompok kontrol menggunakan metode ceramah bervariasi. Perbedaan tersebut dilihat dari skor rata-rata gain, dimana rata-rata gain pada kelompok eksperimen sebesar 4,74 dan rata-rata gain pada kelompok kontrol sebesar 4,24. Dengan demikian, hasil belajar siswa pada kelompok eksperimen yang menggunakan pembelajaran dengan pendekatan keterampilan proses tidak lebih tinggi dibandingkan dengan kelompok kontrol yang menggunakan metode ceramah bervariasi. Perbedaan hasil belajar ini sesuai dengan hasil uji hipotesis dengan menggunakan uji-t dengan taraf signifikansi 5\%.

3. Tidak ada pengaruh yang lebih baik terhadap prestasi belajar siswa pada mata pelajaran geografi dengan menggunakan pembelajaran pendekatan keterampilan proses. Hal tersebut terlihat dari rata-rata gain pada kelompok eksperimen dan kelompok kontrol.

\section{DAFTAR PUSTAKA}

. 2003. Sistem Pendidikan Nasional 2003. Jakarta: Cemerlang.

Arikunto, Suharsimi. 2008. Dasar-Dasar Evaluasi Pendidikan. Jakarta: Bumi Aksara.

Djamarah, Syaiful. 1994. Prestasi Belajar Dan Kompetensi Guru. Surabaya: Gadjah Mada. Hasan, Iqbal. 2004. Analisis Data Penelitian Dengan Statistik. Jakarta: Numi Aksara.

Holil, Anwar. 2008. Tujuan Keterampilan Proses. [Online]. Tersedia: http//:anwarholil.blogspot.com/2008/04/tujuanketerampilanproses.html

Kamil Pasya, Gurniwan. 2002. Geografi Pemahaman Konsep Dan Metodologi. Bandung : Buana

Nusantara

Mappa, Syamsu. 1997. Psikologi Pendidikan. Ujung Pandang: FIP IKIP Ujung Pandang.

Nasution, dkk. 1995. Didaktik Asas-Asas Mengajar. Jakarta: Bina Aksara.

Poedjiadi, Anna. 2005. Sains Teknologi Masyarakat. Bandung: Remaja Rosda Karya.

Sudjana, N. 2008. Penilaian Hasil Proses Belajar Mengajar. Bandung: Remaja Rosda Karya.

Sumaatmadja, N. 1997. Metodologi Pengajaran Geografi. Jakarta: Bumi Aksara.

Tim Pengembang MKDP Kurikulum dan Pembelajaran. 2006. Kurikulum dan Pembelajaran.

Jurusan Kurikulum dan Teknologi Pendidikan. FKIP. Bandung: UPI.

Tirtaraharja, Umar. 1981. Pendekatan Dalam Proses Belajar Mengajar. Bandung: Remaja Rosda

Karya.

Uzer, Usman Moh. 2003. Menjadi Guru Profesional. Bandung: Remaja Rosda Karya.

http://www.ut.ac.id 